\title{
Channel Migration of the Meandering River Fan: A Case Study of the Okavango Delta
}

\author{
Xue Yan ${ }^{1}$, Jinliang Zhang ${ }^{1, *}$, Yang $\mathrm{Li}^{2, *}$ and Long Sun ${ }^{1}$ \\ 1 Faculty of Geographical Science, Beijing Normal University, Beijing 100875, China; \\ 201931051062@mail.bnu.edu.cn (X.Y.); longsun163@163.com (L.S.) \\ 2 Hubei Key Laboratory of Petroleum Geochemistry and Environment, Yangtze University, \\ Wuhan 430100, China \\ * Correspondence: jinliang@bnu.edu.cn (J.Z.); lyugly@163.com (Y.L.)
}

check for updates

Citation: Yan, X.; Zhang, J.; Li, Y.; Sun, L. Channel Migration of the Meandering River Fan: A Case Study of the Okavango Delta. Water 2021, 13, 3319. https://doi.org/10.3390/ w13233319

Academic Editors: Yonggang Jia, Paul Liu and Chaoqi Zhu

Received: 22 September 2021 Accepted: 11 November 2021 Published: 23 November 2021

Publisher's Note: MDPI stays neutral with regard to jurisdictional claims in published maps and institutional affiliations.

Copyright: (c) 2021 by the authors. Licensee MDPI, Basel, Switzerland. This article is an open access article distributed under the terms and conditions of the Creative Commons Attribution (CC BY) license (https:/ / creativecommons.org/licenses/by/ $4.0 /)$.

\begin{abstract}
Okavango delta is a typical distributive fluvial system, which is composed of a series of sand island-river-swamp networks. River migration in the Okavango delta is analyzed by using satellite images from Google Earth and Alaska Satellite Facility (ASF). Four configuration characterization parameters are selected to depict and measure the meandering river. These four parameters are sinuosity index $(S)$, curvature $(C)$, the difference of along-current deflection angle $(\Delta \theta)$ and expansion coefficient $(\mathrm{Km})$. In the fan, the channel migration is mainly asymmetric. According to geomorphic elements and associated features, Okavango Delta can be subdivided into three zones: axial zone, median zone and distal zone. Under the influence of slope, climate and vegetation, different migration modes are developed in different zones. As the river moves downstream, the sinuosity index of the river on the Okavango Delta decreases downstream. Based on the characteristics of different zones, the sedimentary facies model of a single source distributive fluvial system of a meandering river is proposed. The models of channel migration and sedimentary facies have wide application. This research will not only provide a basis for the prediction of future river channels but will also provide important theoretical guidance for the study of the sedimentary morphology of underground reservoirs.
\end{abstract}

Keywords: Okavango delta; low-sinuosity meandering channel; sedimentary configuration; river evolution

\section{Introduction}

With the continuous progress of geomorphology and remote sensing, we can observe the morphology and distribution of a sedimentary system from a macro perspective. The widespread use of remote sensing images enhances researchers' understanding of river morphology and dynamics on the spatial-temporal scale and also provides new ideas and guidance for the study of sedimentary systems [1-4]. In recent years, the study of fluvial depositional systems has become a hotspot in sedimentology and petroleum geology internationally. The interdisciplinary integration in the fields of geomorphology and fluvial sedimentology can systematically and quantitatively study the characteristics of a distributive fluvial system (DFS) from provenance to sedimentary basins. This method has provided valuable insight into in-depth studies of modern channels and the evolution of paleochannels and goes deep into the field of oil and gas exploration. Initial work modeled river morphology, hydrodynamics and meandering structures [5-7]. The authors [8] traced river networks and found that the periodic flow-change controls the river morphology of a given region. Meanwhile, many authors identified the different river migration and meandering loop modes [9-11], and Weissmann et al. [12] used Google Earth to analyze 724 modern sedimentary basins around the world, defined the distributive fluvial system and concluded that most basins were created via distributive river deposits. Hartley et al. [13] defined six types of fluvial planform and seven termination types to categorize 415 large-scale distributive fluvial systems, which provides guidance for the distribution 
of geomorphic features and alluvial sedimentary deposits. Davidson et al. [14] analyzed over 400 fluvial megafans and proposed three generic geomorphic element models using geomorphic elements and associated features. The models can be subdivided into three or four zones, where geomorphic channel and floodplain changes occur.

The scholars have also done a lot of research on river migration structure, but the basic theoretical research on channel configuration and migration evolution is still not perfect. In modern fluvial sedimentology, the evolution of rivers and the distribution of organic matter are controlled by many factors, such as flow, bank type, flow intensity, slope, climate and so on. What and where do patterns develop? What does the migration pattern indicate about the environment? What are the differences and particularities of migration pattern distribution in different zones of DFS? The above problems are worth pondering. The migration law of macro meandering rivers also provide insight into the configuration evolution of ancient channels [15-21], and is particularly important in the prediction of modern rivers. This research takes the Okavango delta as an example. Although predecessors have carried out a lot of research on sedimentary dynamics, fan characteristics and structure, there is less research on river migration models, which is the focus of this paper. This research not only integrates disciplines but also plays an important guiding role in the reconstruction of ancient rivers and guides the exploration for, and development of, oil and gas. At the same time, the migration characteristics of different fluvial zones provide a basis for predicting the hydrodynamic characteristics in DFS, which is the reflection of the ongoing research.

\section{Study Area}

With the deepening of research, the Okavango delta, which is a typical example of DFS, is formed by meandering channel sedimentation; therefore, it is called the Okavango meandering river fan in this paper. Okavango delta, the largest surficial delta fan in the world (area of $15,000 \mathrm{~km}^{2}$ ), is located in the northern part of Botswana, in the Kalahari Desert (Figure 1). The panhandle region of the Okavango River begins in Mohembo and has an average gradient of $\sim 0.00018$ [22]. After flowing through Sepupa, the river passes through the Gomare fault, with a steep slope of $\sim 0.00029$ [23] to form many tributaries and a fan body. The Okavango delta consists of three restricted rivers: the Okavango, Nqoga and Maunachira Rivers [24]. Due to the presence of dense sedges and weeds, these high-permeability river embankments experience strong hydrodynamic forces. While the surrounding areas remain dry year-round, the water in the river maintains both permanent wetlands near the river and seasonal wetlands in the fan [25-27]. The existence of malaria mosquitoes and tsetse flies in the area makes it inhospitable to human beings, which provides unmodified conditions for scientific research [24,28,29].

The Okavango river initially flows through exorheic basins as a single sinuous channel that eventually bifurcates into smaller sinuous channels downstream and finally terminates at an axial fluvial system. The geomorphological characteristics of the delta are also affected by rainfall, infiltration and transpiration [30]. There are many landforms, such as active channels, abandoned channels, lakes, wetlands, swamps, oxbow lakes and floodplains, with revival rivers and crevasse fans [31]. The peak flow in the panhandle occurs in the late summer rainy season, but the passage of seasonal flood waves slows down due to the vegetation in the permanent wetland and the filling of depressions in the seasonal wetland, so the peak flow in the lower fan occurs in the winter dry season [27,32]. Local factors that impact the magnitude and direction of the river flow include riverbank seepage and animal activities such as the night hunting of hippos. 


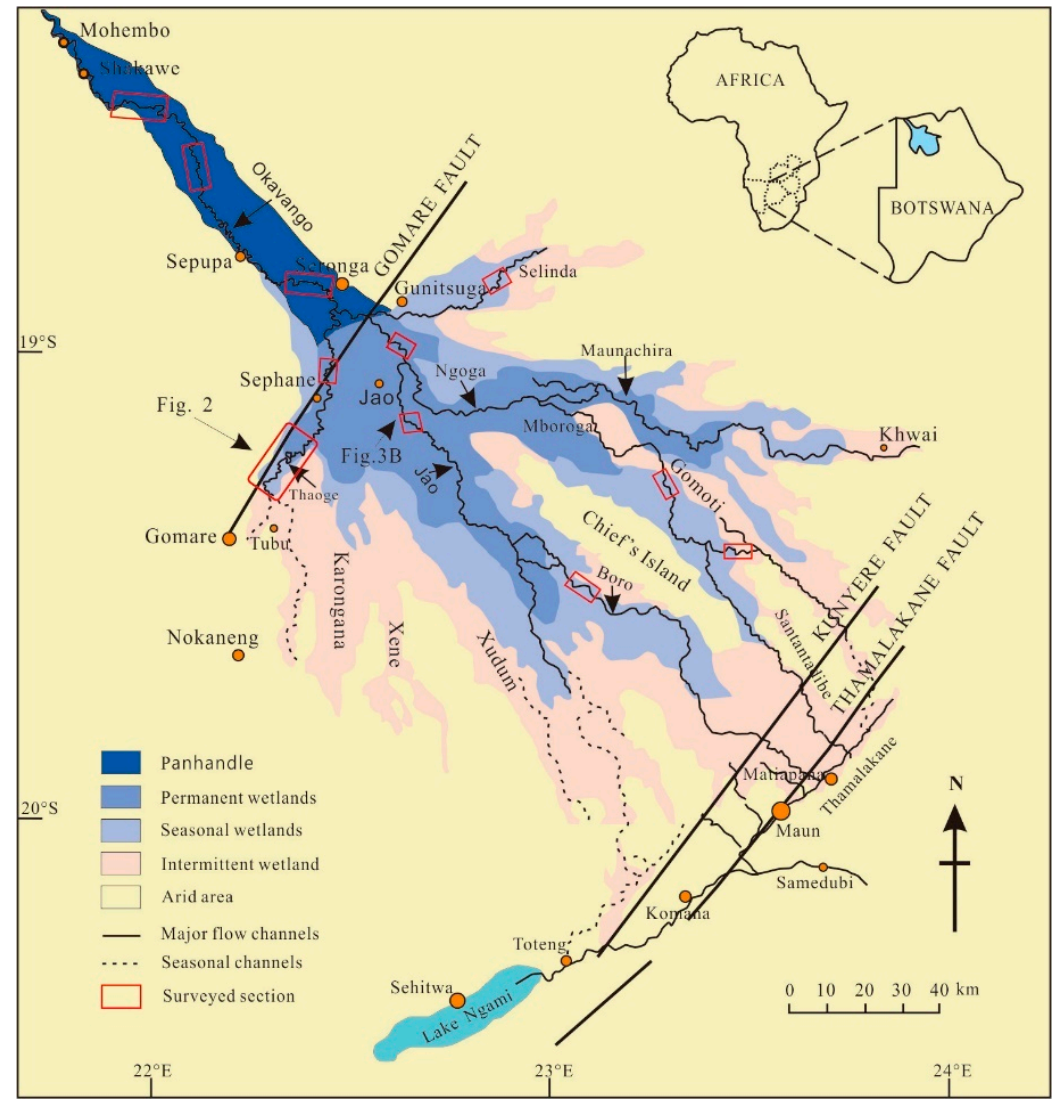

Figure 1. Map of Okavango delta showing the sub-regions, major channels, faults and extent of seasonal and permanent wetlands; red boxes indicate locations of survey sections.

\section{Materials Methods and Terminology}

This research used Google Earth to collect satellite images from the last 10 years and downloaded ALOS (PALSAR) data from the ASF website to observe the characteristics of channel migration. PALSAR is an L-band synthetic aperture radar sensor carried by the Advanced Land Observing Satellite. It can observe the earth all day, without the influence of clouds, weather and day and night, and obtain the data of three observation modes: high-resolution, scanning synthetic aperture radar and polarization. The L-band, with its stronger penetration, allows for more subtle surface deformations to be observed. Conditions for obtaining data include flight direction: ascending, off-nadir angle: 34.3 and spatial resolution: $10 \mathrm{~m}$.

The study of channels on modern alluvial plains remains in the description of sedimentary facies, and the characterization of river morphological migration needs to be improved. River migration configuration elements include static elements, dynamic elements and characterization parameters. Taking a section of the river as an example, its migration is characterized and restored (Figure 2). Based on satellite photos, 4 static elements, 8 dynamic elements and 4 characterization parameters were selected to qualitatively and quantitatively characterize the meandering channel (Figure 3). The centerline simplifies the complexities of the channel in order to facilitate the analysis of its migration and evolution. Static and dynamic elements were measured in Google Earth, and the 4 characterization parameters were calculated in combination with the formula. The characterization parameters include the sinuosity index $(S)$, the curvature $(C)$, the difference in the along-current deflection angle $(\Delta \theta)$ and the expansion coefficient $(\mathrm{Km})$. The related definitions are shown here. 


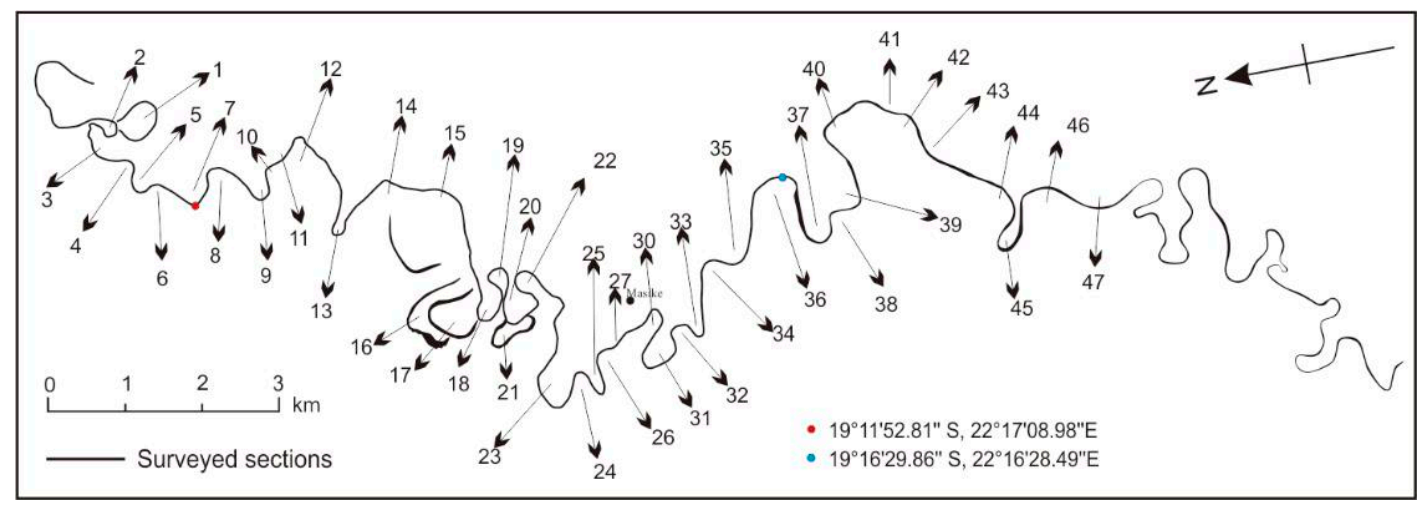

Figure 2. The channel morphology and location of meandering loops in a section of the Thaoge river.

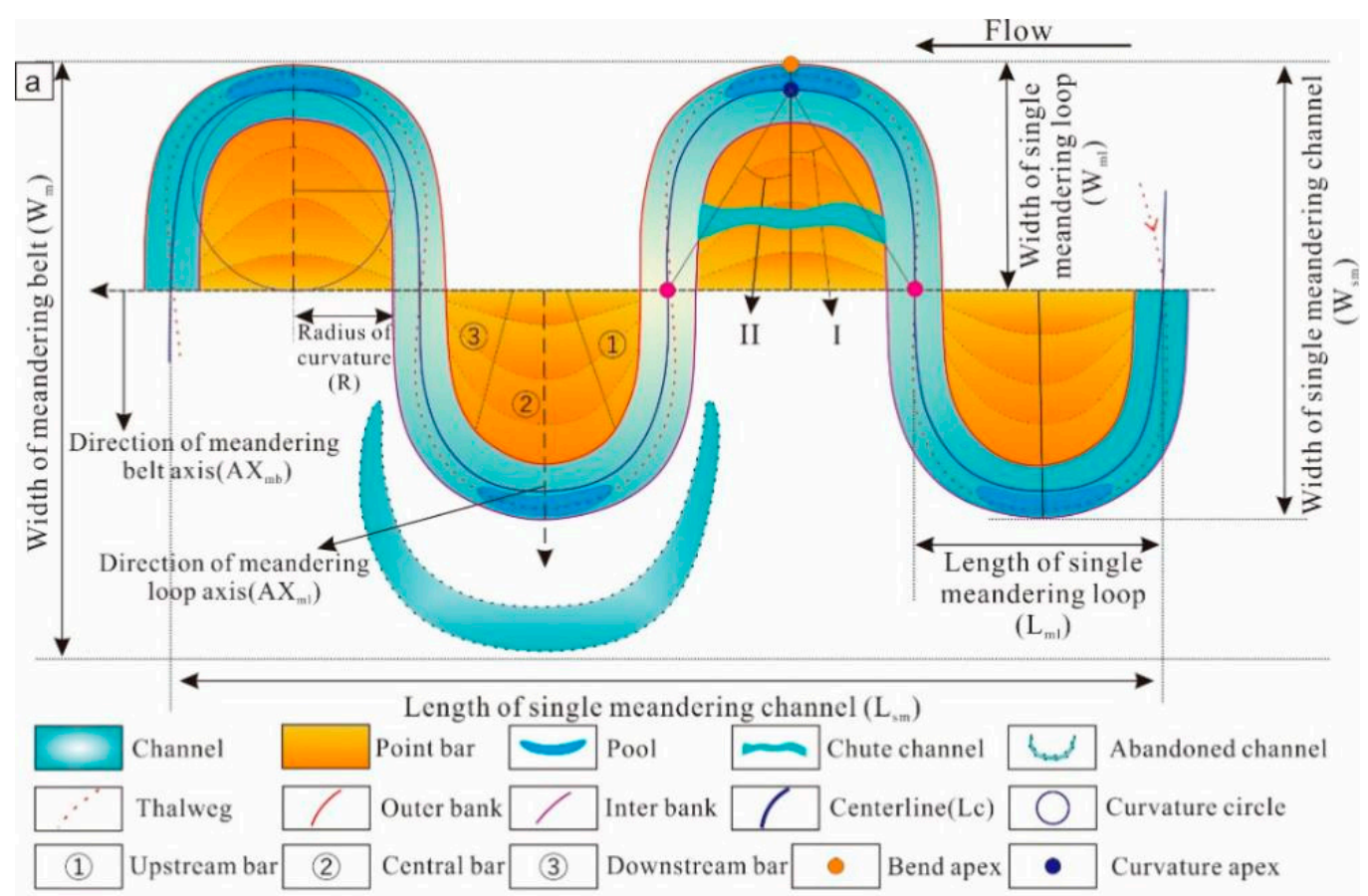

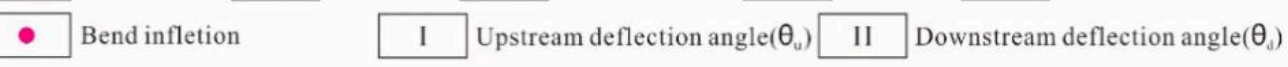

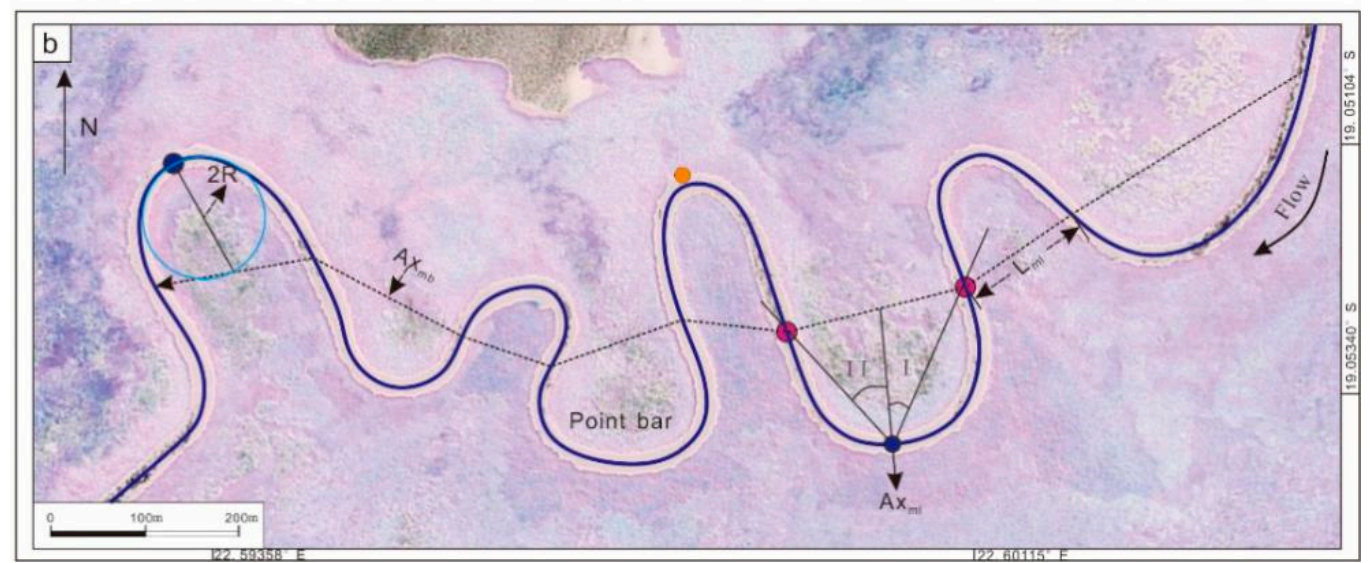

Figure 3. Planform migration architectural elements of a meandering channel. (a) Migration structures in an ideal meandering river [33-35]. (b) Satellite image of the section of Jao River (Figure 1). 
In this paper, curvature apex was used, which is the midpoint of the connecting line between the outer bank apex and the inner bank apex of the meandering loop. Bend apex is located at the edge of the outer bank. Bend inflection is the transition position to the adjacent meander loop. The centerline ( $\mathrm{Lc}$ ) is defined as the line connecting the central points of the outer and inner bank edges for all cross-sections of the river; the centerline reflects the actual length of a given river section. The length of a single meander loop $\left(\mathrm{L}_{\mathrm{ml}}\right)$ is the distance between the bend inflections of adjacent meander bends. The axis of the meander belt $\left(\mathrm{AX}_{\mathrm{mb}}\right)$ is also the connecting line for the adjacent bend inflections, which represents the flow direction of the river; its length is equal to $\mathrm{L}_{\mathrm{ml}}$, expressed by $\left|\mathrm{AX}_{\mathrm{mb}}\right|$. The axis of the meandering loop $\left(\mathrm{AX}_{\mathrm{ml}}\right)$ is the line between the curvature apex and the midpoint of two adjacent bend inflections, which points in the expansion direction of the outer bank. The upstream deflection angle $(\theta \mathrm{u})$ is the angle between $\mathrm{AX}_{\mathrm{ml}}$ and a line that connects the curvature apex and the upstream bend inflection. The downstream deflection angle $(\theta \mathrm{d})$ is the angle between $A X_{\mathrm{ml}}$ and the line that connects the curvature apex and downstream bend inflection. The radius of curvature $(R)$ is defined as half the length from the curvature apex to halfway along $\mathrm{L}_{\mathrm{ml}}$. The length of a single meandering channel $\left(\mathrm{L}_{\mathrm{sm}}\right)$ is the sum of the $\left|\mathrm{AX} X_{\mathrm{mb}}\right|$ of the single meander belt from the beginning to the end. The width of the meandering belt $\left(\mathrm{W}_{\mathrm{m}}\right)$ is the migration width of the multi-stage composite channel. The width of a single meandering belt $\left(\mathrm{W}_{\mathrm{sm}}\right)$ is the migration width of the single channel. The width of a single meandering loop $\left(\mathrm{W}_{\mathrm{ml}}\right)$ is the vertical distance from the bend apex of the meander loop to the $\mathrm{AX}_{\mathrm{mb}}$ (Figure 3).

Sinuosity index was calculated as $\left(\mathrm{S}=\mathrm{Lc} /\left|\mathrm{AX} \mathrm{mb}_{\mathrm{mb}}\right|\right)$. The centerline represents the actual channel length, and the length of the axial line represents the straight-line length of the channel, which can better reflect the migration of the channel.

The curvature was calculated as $(C=1 / R)$. The curvature circle and the curvature radius are determined using the curvature apex.

The difference in the along-current deflection angle $(\Delta \theta=\theta \mathrm{u}-\theta \mathrm{d})$ is the difference between the upstream deflection angle $(\theta \mathrm{u})$ and the downstream deflection angle $(\theta \mathrm{d})$. It reflects the symmetry of the river bend. When this angle is close to zero, the river bend is more symmetric. If this parameter is positive, the curvature apex points upstream; if it is negative, the curvature apex points downstream.

The expansion coefficient is given as $(\mathrm{Km}=\mathrm{Lml} / 2 \mathrm{R}) . \mathrm{Km}$ reflects the degree of expansion convergence in the meandering channel. When $\mathrm{Km}$ is greater than 1 , the meandering channel is experiencing a period of expansion, and when $\mathrm{Km}$ is less than 1 , the channel is contracting.

In the fan, 11 meandering sections and 203 meandering loops were selected for analysis (Figure 1). Based on the data and morphological characteristics, the migration model and law are summarized. Focusing on Figure 2, the early meandering river is restored and reconstructed. When these methods are applied to the river system, the models and controlling factors in different zones are discussed, which is of great significance to modern river prediction and ancient river reconstruction.

\section{Results}

In Figure 2 (Thaoge River), the morphology of point bars and the evolution of channel migration are quantitatively studied by combining the morphological and structural characterization parameters. In the process of river migration, the concave bank is eroded away, and sediments are continuously deposited on the convex bank. During the river migration process, meandering channels may be abandoned, as the ongoing river erosion causes the river channel to straighten. Using satellite images to measure the distributary rivers of the Okavango delta, we determined that the length of the individual meander loop $\left(\mathrm{L}_{\mathrm{ml}}\right)$ ranges from $123 \mathrm{~m}$ to $1164 \mathrm{~m}$, the centerline length $(\mathrm{Lc})$ has values between $167 \mathrm{~m}$ and $1960 \mathrm{~m}$ and the radius of curvature (R) ranges from $14 \mathrm{~m}$ to $400 \mathrm{~m}$. The length of the meander belt $\left(\left|\mathrm{AX} X_{\mathrm{mb}}\right|\right)$ falls between $123 \mathrm{~m}$ and $1164 \mathrm{~m}$, the direction ranges from $100^{\circ}$ to $300^{\circ}$, the axial direction of the meander loop has values that fall between $10^{\circ}$ and $327^{\circ}$ 
and the upstream deflection angle $(\theta \mathrm{u})$ and downstream deflection angle $(\theta \mathrm{d})$ have values ranging from $6^{\circ}$ to $56^{\circ}$ and from $5^{\circ}$ to $55^{\circ}$, respectively (Table 1 ). As such, meandering rivers tend to either be in periods of expansion (growing meanders, $\mathrm{Km}>1$ ) or contraction (abandoning meanders, $\mathrm{Km}<1$ ).

Table 1. The planform architectural elements and parameter values for key loops in Figure 2.

\begin{tabular}{|c|c|c|c|c|c|c|c|c|c|c|}
\hline Loop Units & 5 & 12 & 15 & 17 & 23 & 24 & 31 & 33 & 37 & 46 \\
\hline Latitude & $19^{\circ} 11^{\prime} 25^{\prime \prime} \mathrm{S}$ & $19^{\circ} 12^{\prime} 54^{\prime \prime} \mathrm{S}$ & $19^{\circ} 13^{\prime} 56^{\prime \prime} \mathrm{S}$ & $19^{\circ} 14^{\prime} 15^{\prime \prime} \mathrm{S}$ & $19^{\circ} 14^{\prime} 17^{\prime \prime} \mathrm{S}$ & $19^{\circ} 14^{\prime} 34^{\prime \prime} \mathrm{S}$ & $19^{\circ} 15^{\prime} 13^{\prime \prime} \mathrm{S}$ & $19^{\circ} 15^{\prime} 35^{\prime \prime} \mathrm{S}$ & $19^{\circ} 16^{\prime} 39^{\prime \prime} \mathrm{S}$ & $19^{\circ} 18^{\prime} 02^{\prime \prime} \mathrm{S}$ \\
\hline Accuracy & $22^{\circ} 17^{\prime} 19^{\prime \prime} \mathrm{E}$ & $22^{\circ} 16^{\prime} 41^{\prime \prime} \mathrm{E}$ & $22^{\circ} 15^{\prime} 49^{\prime \prime} \mathrm{E}$ & $22^{\circ} 15^{\prime} 49^{\prime \prime} \mathrm{E}$ & $22^{\circ} 15^{\prime} 08^{\prime \prime} \mathrm{E}$ & $22^{\circ} 15^{\prime} 18^{\prime \prime} \mathrm{E}$ & $22^{\circ} 15^{\prime} 15^{\prime \prime} \mathrm{E}$ & $22^{\circ} 15^{\prime} 23^{\prime \prime} \mathrm{E}$ & $22^{\circ} 15^{\prime} 54^{\prime \prime} \mathrm{E}$ & $22^{\circ} 15^{\prime} 36^{\prime \prime} \mathrm{E}$ \\
\hline $\operatorname{Lml}(\mathrm{m})$ & 272 & 138 & 293 & 253 & 459 & 305 & 293 & 334 & 474 & 217 \\
\hline $\mathrm{Lc}(\mathrm{m})$ & 410 & 480 & 880 & 1279 & 1160 & 540 & 1148 & 539 & 1000 & 833 \\
\hline $\mathrm{R}(\mathrm{m})$ & 71 & 106 & 176 & 181 & 234 & 102 & 232 & 106 & 187 & 205 \\
\hline$\underset{(\mathrm{m})}{|\underset{\mathrm{A}}{\mathrm{A}} \mathrm{Xb}|}$ & 272 & 138 & 293 & 253 & 459 & 305 & 293 & 334 & 474 & 217 \\
\hline $\mathrm{AXmb}\left({ }^{\circ}\right)$ & 227.9 & 225.4 & 162.7 & 196.7 & 235.9 & 181.8 & 200.1 & 138.9 & 207.2 & 183.7 \\
\hline $\mathrm{AXml}\left({ }^{\circ}\right)$ & 303 & 308 & 307 & 256 & 290 & 79 & 315 & 270 & 268 & 319 \\
\hline$\theta \mathrm{u}\left({ }^{\circ}\right)$ & 34 & 18 & 24 & 15 & 19 & 38 & 21 & 56 & 22 & 13 \\
\hline$\theta \mathrm{d}\left({ }^{\circ}\right)$ & 55 & 19 & 12 & 21 & 33 & 33 & 16 & 13 & 41 & 9 \\
\hline S & 1.51 & 3.49 & 3.00 & 5.06 & 2.52 & 1.77 & 3.91 & 1.61 & 2.11 & 3.84 \\
\hline $\mathrm{C}$ & 0.0142 & 0.0094 & 0.0057 & 0.0055 & 0.0043 & 0.0098 & 0.0043 & 0.0095 & 0.0053 & 0.0049 \\
\hline$\Delta \theta\left(^{\circ}\right)$ & -21 & -1 & 12 & -6 & -14 & 5 & 5 & 43 & -19 & 4 \\
\hline $\mathrm{Km}$ & 1.92 & 0.65 & 0.83 & 0.70 & 0.98 & 1.49 & 0.63 & 1.58 & 1.27 & 0.53 \\
\hline
\end{tabular}

(1) $\mathrm{S}=\mathrm{Lc} / \mathrm{Axmb}$; (2) $\mathrm{C}=1 / \mathrm{R}$; (3) $\Delta \theta=\theta \mathrm{u}-\theta \mathrm{d}$ [36]; (4) $\Delta \theta^{\prime}=\theta \mathrm{d}-\theta \mathrm{c}$ [36]; (5) $\mathrm{Km}=\mathrm{Lml} / 2 \mathrm{R}$ [36].

\subsection{Geomorphological Migration Characteristics and Models}

During migration, meandering river expansion coincides with the continuous outward erosion and migration of the river. In this scenario, $\mathrm{Km}$ is usually greater than 1 , which is called the expansion model. When the river expansion slows and the erosion intensifies near the bend inflections, some meandering channels may be abandoned, which is called the contraction model with a Km typically less than one. Combined with $\Delta \theta$, the migration structure can be subdivided into a symmetrical structure, upstream rotation structure and downstream rotation structure. Six single models and three compound models were developed.

\subsection{Expansion Model}

Meandering river expansion coincides with the continuous outward erosion and migration of the river. In this scenario, Lc increases gradually, and $|\mathrm{AXmb}|$ is largely stable but may decrease slowly. $\mathrm{S}$ and $\mathrm{R}$ increase, while $\mathrm{C}$ gradually decreases, and $\mathrm{Km}$ is greater than one. Depending on the migration direction of the point bar, the $\Delta \theta$ value and the expansion structure can be classified (Figure 4a) into three sub-categories: symmetrical expansion migration (SEM), upstream rotation expansion migration (UREM) and downstream rotation expansion migration (DREM).

As shown in loop 24 (Figure 5), $\Delta \theta$ is close to $0^{\circ}$, and the SEM curvature apex is a relatively straight line. Loop 24 is an example of a symmetrical expansion structure. The sinuosity index $S$ is 1.77 , and the curvature $C$ has a value of $0.0098 \mathrm{~m}^{-1}$. With a difference in the along-current deflection angle $\Delta \theta$ of $5^{\circ}$, we can see that the meander is symmetric with a tendency to rotate slightly upstream. Furthermore, with a Km of 1.49 , we have determined that this loop is currently in a period of expansion.

In the shown loop 33 (Figure 6), the curvature apex points toward the upstream direction, and this line exhibits a distinct curvature with a $\Delta \theta$ value that is greater than 0 . For loop 33, the sinuosity index $S$ is 1.61 , and the curvature $C$ is $0.0095 \mathrm{~m}^{-1}$. With a difference in the along-current deflection angle $\Delta \theta$ of $43^{\circ}$, we see that the curvature apex is close to the upstream direction, exhibiting a strong trend of upstream rotation. With a Km value of 1.58 , we infer that this section of the river is currently in a stage of rapid expansion. 

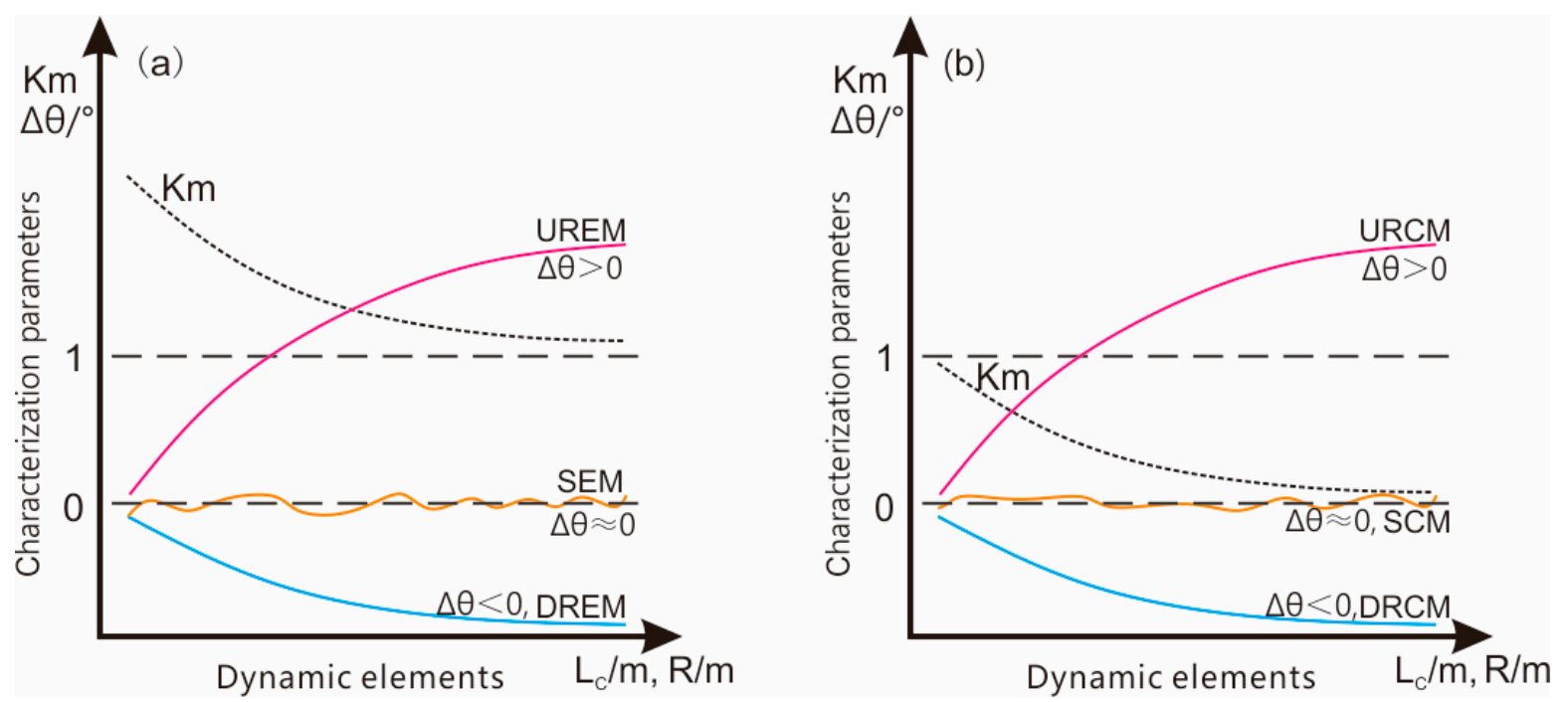

Figure 4. Parameter characteristics of migration mode. (a) Variation trend of expansion migration characterization parameter values with river migration. (b) The variation trend of contraction migration characterization parameter values with river migration. SEM is the symmetrical expansion migration, UREM is the upstream rotation expansion migration, DREM is the downstream rotation expansion migration, SCM is the symmetrical contraction migration, URCM is the upstream rotation contraction migration, DRCM is the downstream rotation expansion migration.

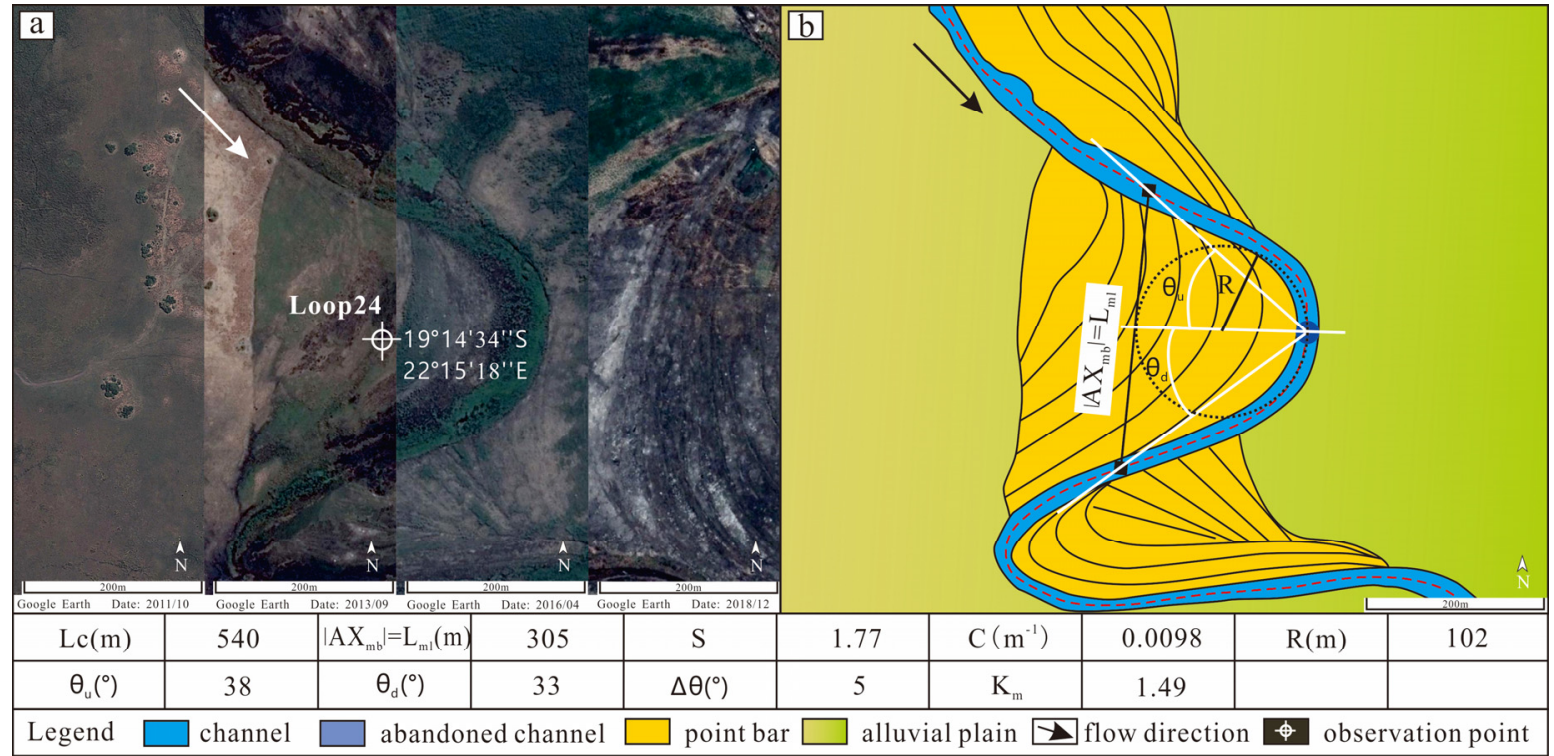

Figure 5. Migration configuration of a symmetrical expansion structure (loop 24). (a) a satellite image of loop 24 taken by Google Earth in recent years; (b) a planar depiction of the migration structural elements of loop 24.

In the DREM shown in loop 37 (Figure 7), the curvature apex points toward the downstream direction, and the $\Delta \theta$ value is less than $0^{\circ}$. In loop 37, the sinuosity index $\mathrm{S}$ is 2.11 , and the curvature $C$ is $0.0053 \mathrm{~m}^{-1}$. With a difference in the along-current deflection angle $\Delta \theta$ of $-19^{\circ}$, we can see that the curvature apex is in the downstream direction. Based on the $\mathrm{Km}$ value of 1.27 , we infer that this loop is in a period of rapid expansion.

\subsection{Contraction Model}

Eventually, the river expansion slows, and the erosion intensifies near the bend inflections; some meandering channels may become abandoned by neck cut-off. In this scenario, Lc increases gradually, and $|\mathrm{AXmb}|$ generally maintains a stable value but may decrease slowly. $\mathrm{S}$ and $\mathrm{R}$ increase, $\mathrm{C}$ decreases, and $\mathrm{Km}$ is less than one (Figure $4 \mathrm{~b}$ ). 
Sub-types of contraction migration include symmetrical contraction migration (SCM), upstream rotation contraction migration (URCM) and downstream rotation contraction migration (DRCM).

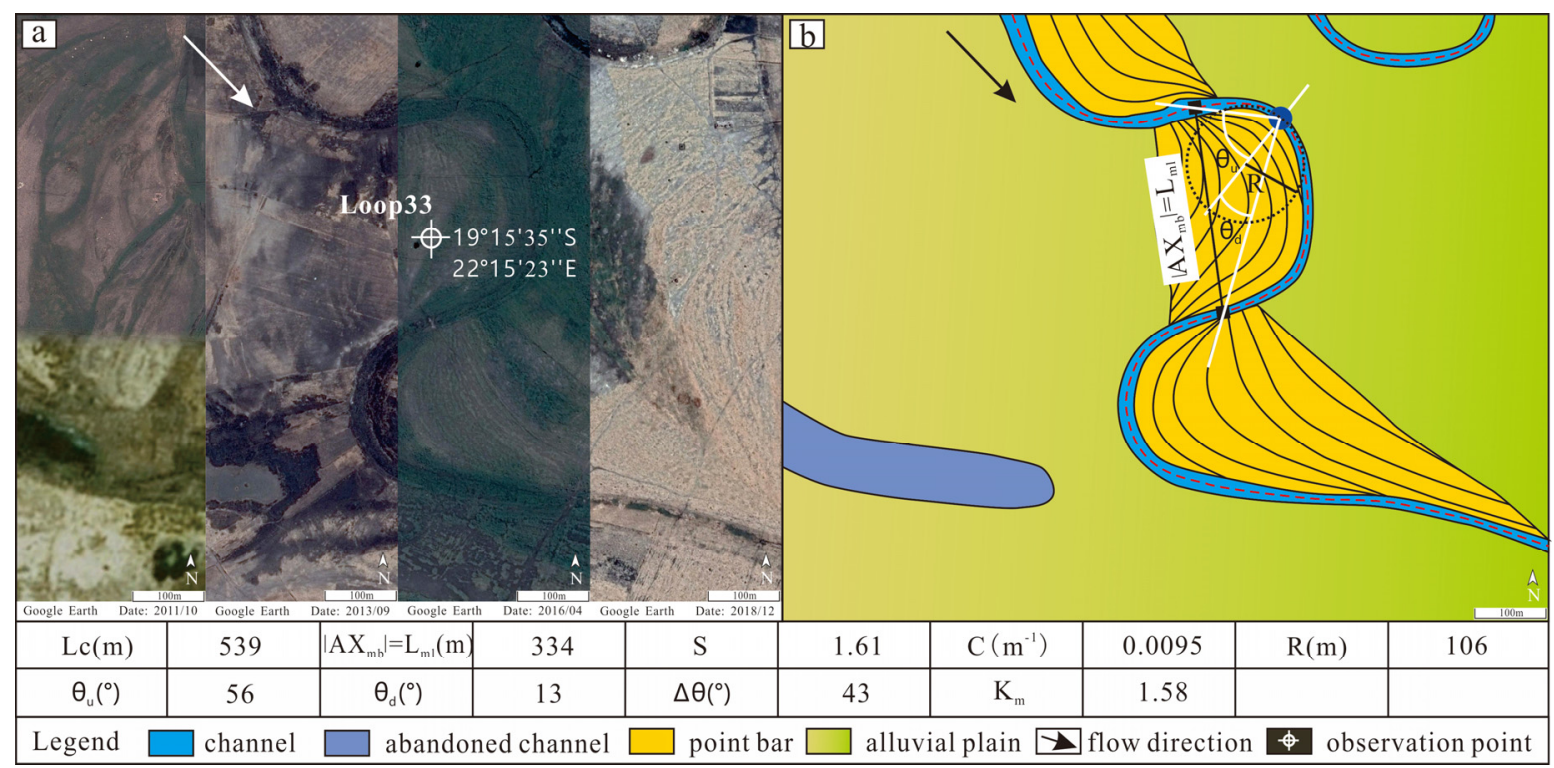

Figure 6. Migration configuration of an upstream rotation expansion structure (loop 33). (a) a satellite image of loop 33 taken by Google Earth in recent years; (b) a planar depiction of the migration structural elements of loop 33.

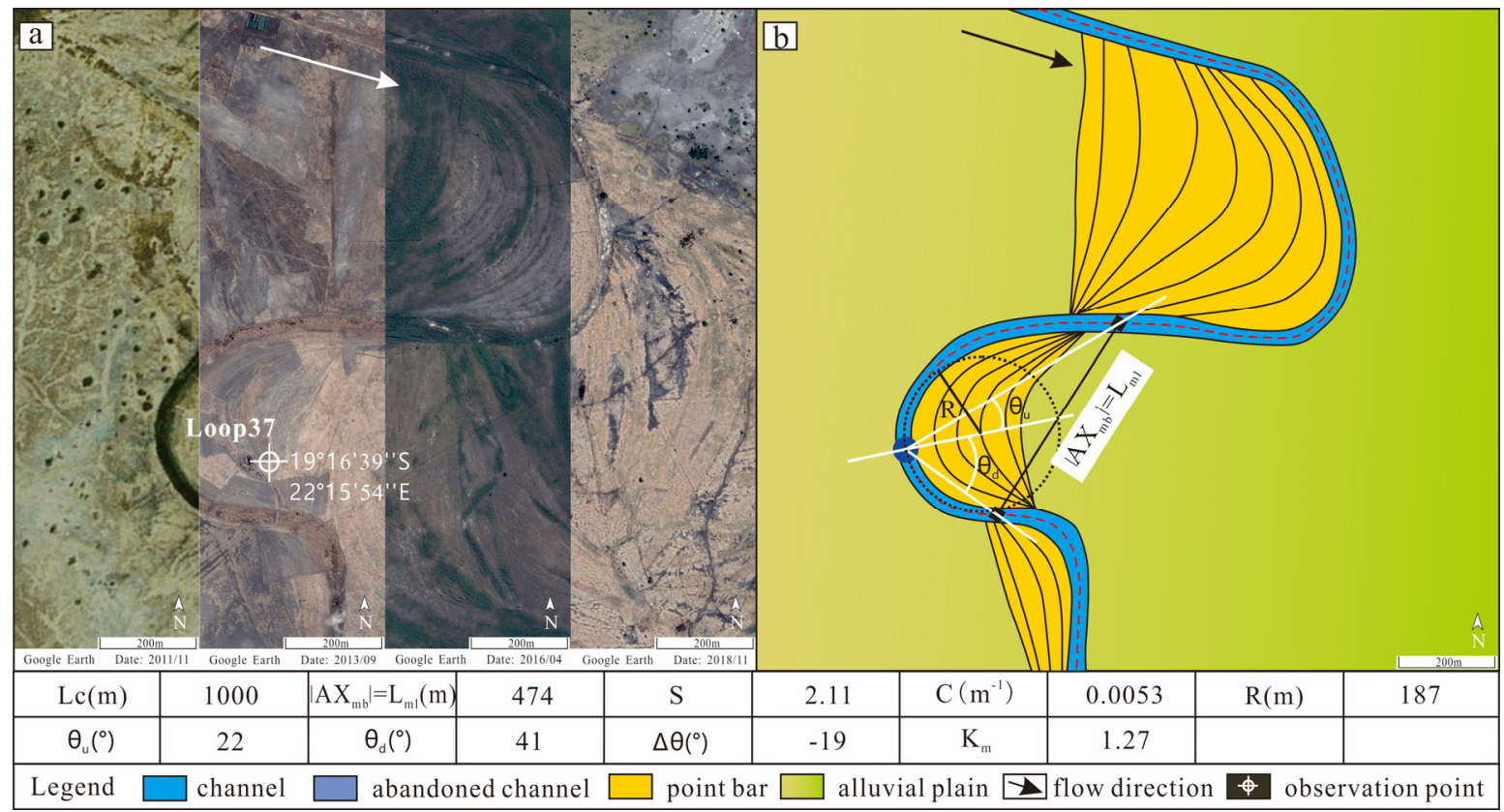

Figure 7. Migration configuration of a downstream rotation expansion structure (loop 37). (a) a satellite image of loop 37 taken by Google Earth in recent years; (b) a planar depiction of the migration structural elements of loop 37.

In the SCM shown in loop 31 (Figure 8), when $\Delta \theta$ is close to $0^{\circ}$, the line of curvature apices is nearly straight, and the upstream deflection is similar to that of the downstream deflection when the river contracts. As shown in Figure 7, for loop 31, the sinuosity index $S$ is 3.91, and the curvature $C$ is $0.0043 \mathrm{~m}^{-1}$. With a difference in the along-current deflection angle $\Delta \theta$ of $5^{\circ}$, this section of the river exhibits a high degree of bending and a weak upstream rotational trend. Based on the $\mathrm{Km}$ value of 0.63 , loop 31 is in a period of rapid contraction. 
In the URCM shown in loop 15 (Figure 9), $\Delta \theta$ is greater than $0^{\circ}$ and the curvature apex points in the upstream direction. The sinuosity ratio is three, and the curvature $C$ is $0.057 \mathrm{~m}^{-1}$. With a moderate difference in the along-current deflection angle $\Delta \theta$ of $12^{\circ}$, loop 15 exhibits a high degree of bending and a significant upstream rotational trend. With its $\mathrm{Km}$ value of 0.83 , we conclude that loop 15 is in a period of significant contraction.

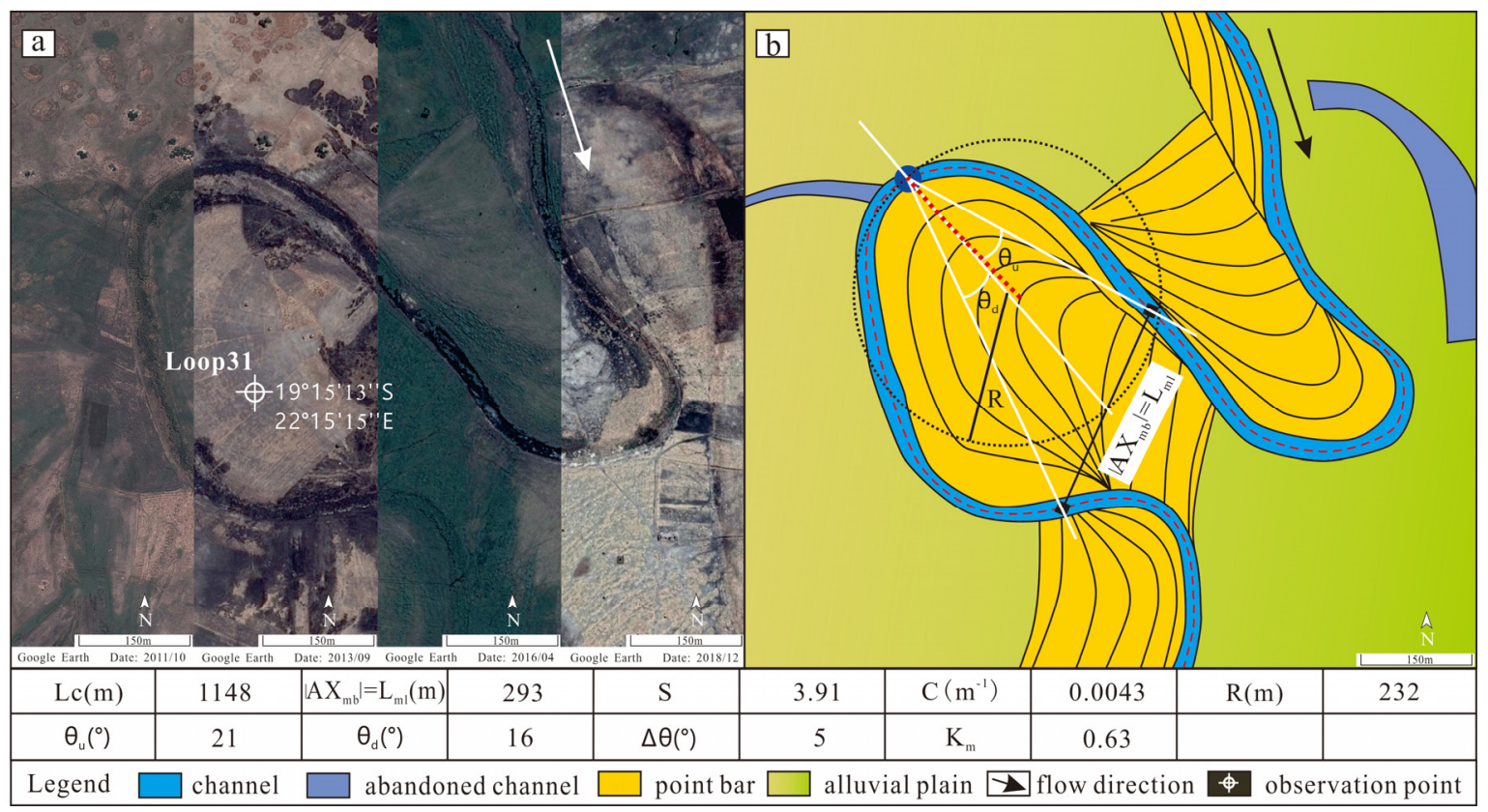

Figure 8. Migration configuration of a symmetric contraction structure (loop 31). (a) a satellite image of loop 31 taken by Google Earth in recent years; (b) a planar depiction of the migration structural elements of loop 31.

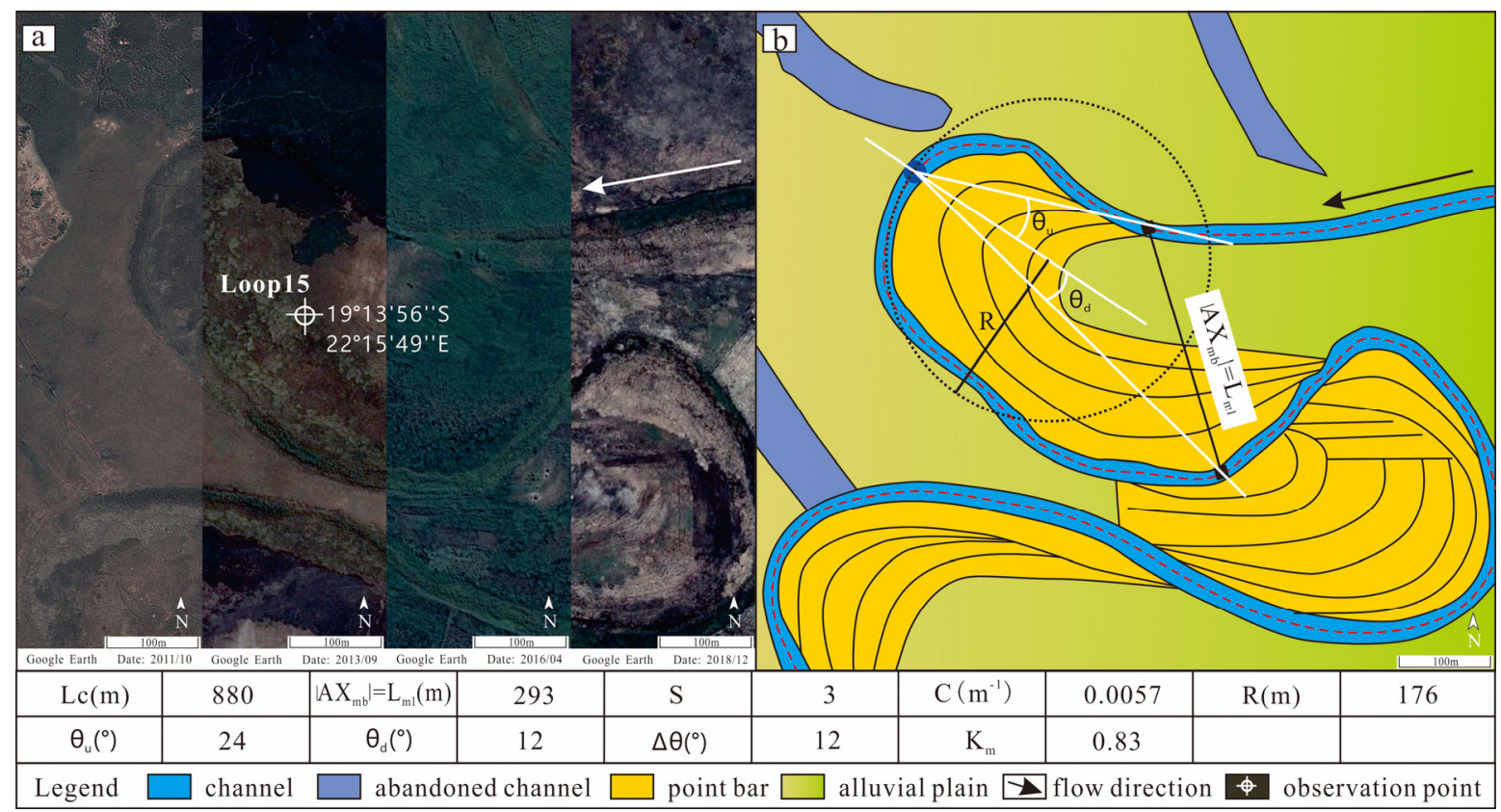

Figure 9. Migration configuration of an upstream rotation contraction structure (loop 15). (a) a satellite image of loop 15 taken by Google Earth in recent years; (b) a planar depiction of the migration structural elements of loop 15.

In the DRCM shown in loop 23 (Figure 10), $\Delta \theta$ is less than $0^{\circ}$, and the curvature apex points in the downstream direction. In loop 23, the sinuosity index $\mathrm{S}$ is 2.52 , and the curvature $C$ is $0.043 \mathrm{~m}^{-1}$. With a difference in the along-current deflection angle $\Delta \theta$ of 
$-14^{\circ}$, it exhibits a downstream rotational trend. Because the $\mathrm{Km}$ value is 0.98 , we conclude that loop 23 is in a period of minimal contraction.

\subsection{Compound Migration}

The migration of rivers is driven by many factors, including the terrain slope, climate, anti-erosion ability, vegetation, sediment concentration and biological activities. As such, it is possible to develop more complex modes of migration, including symmetrical expansion and contraction migration (SE $+\mathrm{CM}$ ), upstream rotation expansion and contraction migration (URE $+\mathrm{CM})$ and downstream rotation expansion and contraction migration $(\mathrm{DRE}+\mathrm{CM})$, as shown in Figure 11.

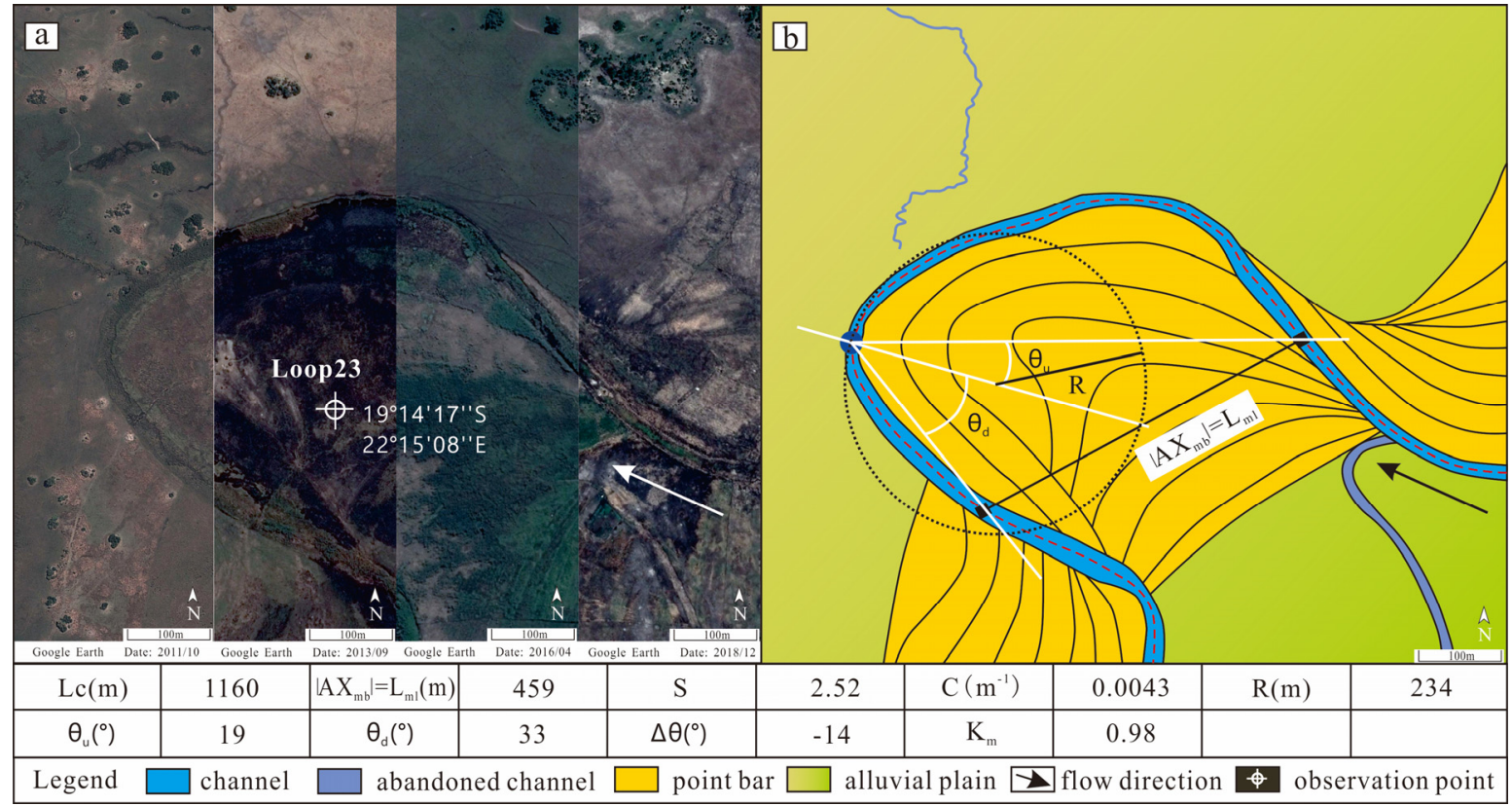

Figure 10. Migration configuration of a downstream rotation contraction structure (loop 23). (a) a satellite image of loop 23 taken by Google Earth in recent years; (b) a planar depiction of the migration structural elements of loop 23.

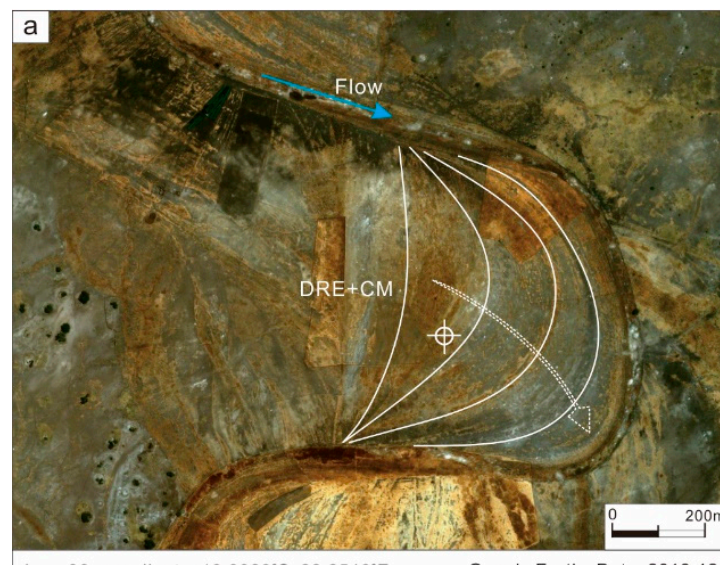

Loop36 coordinate: $19.3329^{\circ} \mathrm{S}, 22.2546^{\circ} \mathrm{E}$

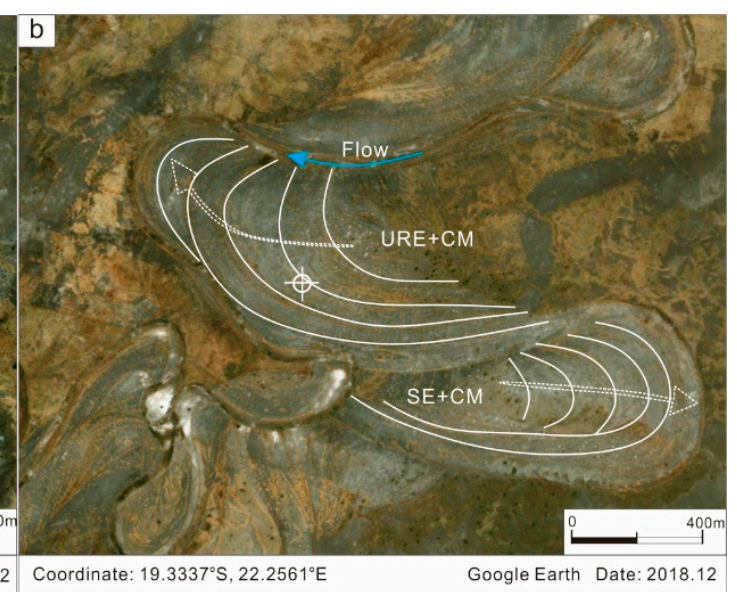

Google Earth Date: 2018.12

Figure 11. Characteristics of a typical compound migration structure in the Thaoge river. (a) shows the plane features of DRE + CM, and (b) shows the plane features of URE + CM and SE + CM.

\section{Discussion}

\subsection{Application of River Reconstruction}

Using satellite image data, we analyze the internal structure of single loops and point bars in the Thaoge River, which flows from north to south. Particularly apparent in the 
river are UREM (loop 8, 11, 12 and 32, etc.) and DREM (loop 5, 26 and 37, etc.). SEM (loop 9, 24 and 31), SCM (loop 17, 31) and URCM (loop 15, etc.) are less developed, and DRCM (loop 23) occurred locally. Six single models and three compound models were developed to explain river migration. The combination of each meander segment constitutes the multi-stage migration evolution of the channel, and the maximum east-west extent was close to $3700 \mathrm{~m}$ (Figure 12). The upstream meander belt swings westward, and the bend inflections are often straightened through erosion. Transverse swing space is limited by the topography and vegetation. The downstream meander belt swings eastward, accompanied by frequent river abandonment and the development of crevasses. Due to the influence of seasonal rainfall [37], chute channels develop occasionally, and the river channel is periodically abandoned and revived. The river diversions and branches can also be seen, and abandoned branches in the rainy season will occasionally revive. Based on the analysis of the internal structure of point bar and meandering channel sedimentation processes, the sedimentary structures of 1-47 meanders (Figure 2) in the study were restored, and the internal structure was refined when combined with the above migration patterns. Five point bar sequences and four abandoned channels were identified, while the initial channel could not be accurately identified or located due to the channel erosion and redeposition (Figure 12). While it may be straightforward to observe the differences between the ancient and modern river sediments, it is difficult to directly apply modern sedimentary mesoscale parameters to the paleoenvironment [38]. Fortunately, the corresponding relationship between the migration model and vertical sedimentation is of great significance to the evolution of the paleochannel internal configuration. With further research, the in-depth study of geomorphological morphology is expected to provide a basis for predicting the future migration direction of the river.

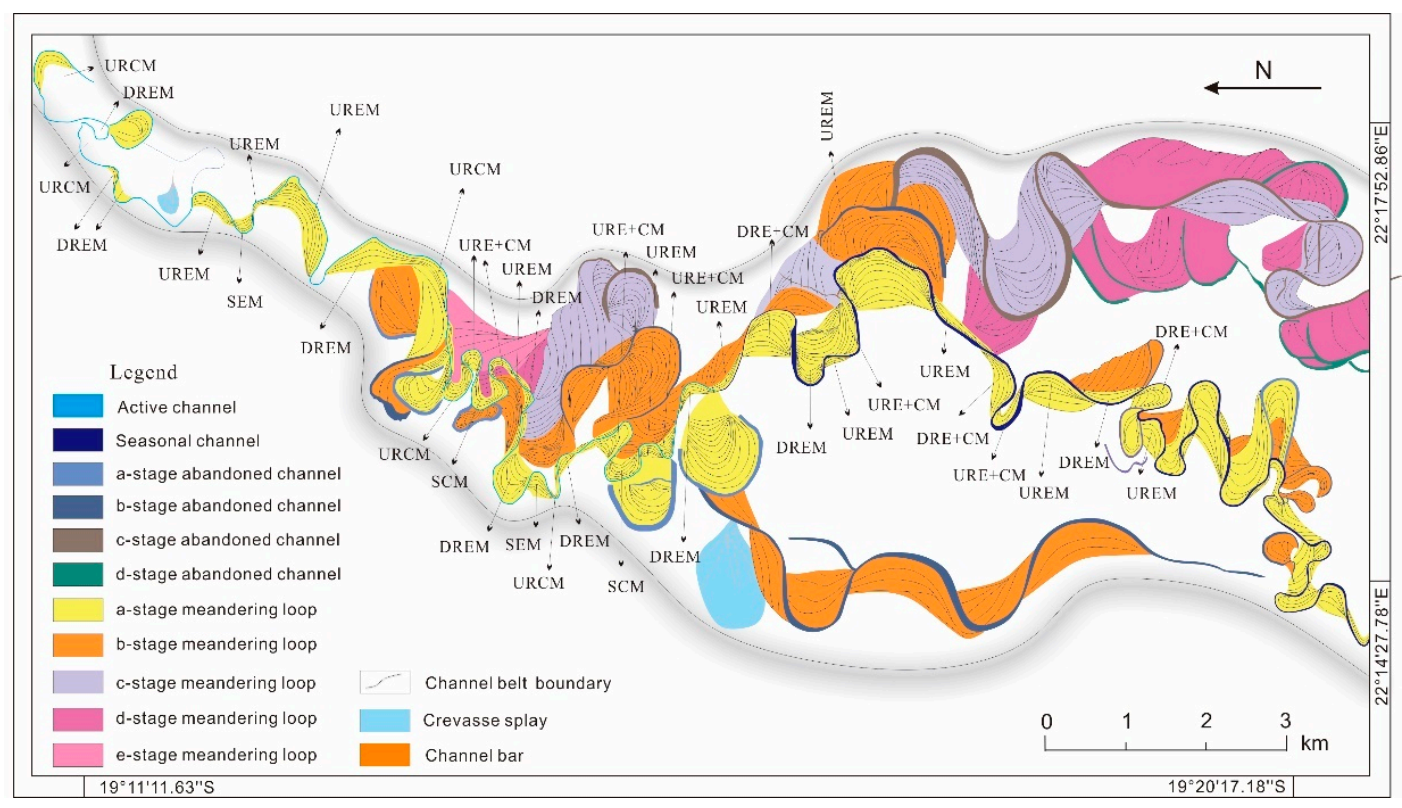

Figure 12. The migration states of meanders 1-47 in the Thaoge River, located in the median zone of the Okavango delta.

In addition to the above point bar of migration modes, certain river features occur during the river migration process, including cut-offs, channel reactivation, breaches, diversions, crevasse abandonment and the development of approximate channel bars [31]. These phenomena play an important role in river restoration and reconstruction. For the purposes of river reconstruction, it is necessary to keep track of abandoned channels, identify the main and chute channels, explore the relationship between the point bar and the channel, genetically differentiate the various abandoned channels, record the orientation of the point bar with respect to the flow direction and recreate a chronological sequence of the 
abandonment of the various meanders [39]. These factors all provide valuable information about channel sedimentation, which is a crucial part of river restoration.

\subsection{Spatial Distribution of Migration Models in the Okavango DFS}

In the Okavango DFS, the dominant multi-thread channel anabranches and bifurcates with increasing frequency as distance increases downstream, thereby creating smaller channels with varying sinuosity. Geomorphic elements and associated features in different zones-changes in morphology and sediment transport caliber and capacity, an overall decrease in channel width, an overall decrease in channel depth, an increase in channel avulsion and sinuosity - behave differently with increasing distance from the apex. In the distributive fluvial system (DFS), channel migration occurs quickly near the apex, while weak erosion develops in more gently sloping regions. Based on geomorphic elements and associated features, we divide the Okavango delta into three zones, which are the axial zone, median zone and distal zone, with increasing distance from the apex (Figure 13). Lateral channel migration is prevalent in proximal and medial regions, as evidenced by point bar deposition in the axial zone and median zone.

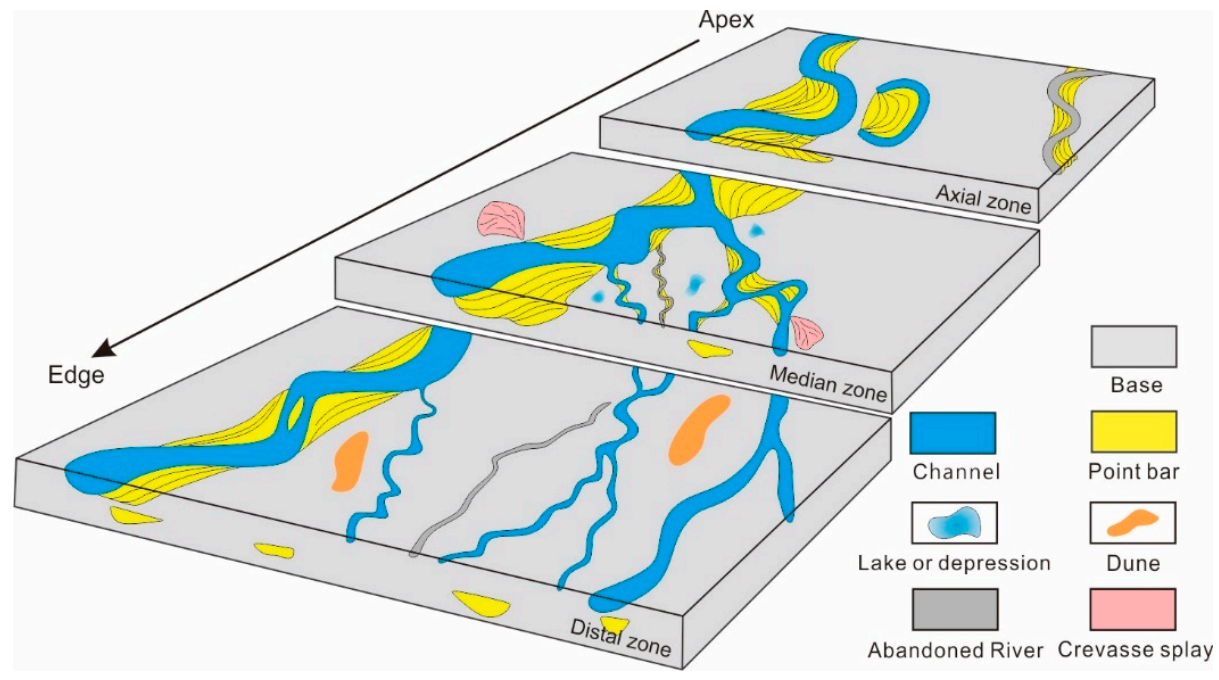

Figure 13. Variation of sedimentary characteristics in different zones of single provenance meandering river fan.

Based on the above parameters and Carlston's [40] (1965) hydrodynamic empirical formula, the mean values of different zones were compared. The sinuosity index and annual average discharge decreased from the top to the end, while the curvature increased. The average $\mathrm{Km}$ in the system was greater than one; thus, the river channel is mainly in expansion (Table 2 and Figure 14). The axial zone, which is located in the panhandle area, is located in an incised river valley with relatively coarse sediments. The channel migrates frequently, resulting in channel-belt deposits in this zone. Despite the development of large compound point bars and flood plain swamps, this region is well-drained and does not have stagnant depressions. Overall, the axial zone is dominated by expansion migration (DREM and UREM, local SEM, Figure 14); compound migrations are URE + CM and $\mathrm{SE}+\mathrm{CM}$ features, with less contraction migration. The median zone is located in the central part of the Okavango delta. While the widths and curvatures for these channels are reduced, the well-drained floodplains and wetlands are larger than those of the axial zone. Small-scale point bars build vertically while the channel migrates laterally. Single migration (DREM, Figure 14) develops in the median zone, while SE + CM and DRE + CM were more developed in the compound migration. The distal zone is located in the middlelower reaches of the river. The efficiency of the drainage decreases with the decline in the strength of the hydrodynamic forces in this zone; while the number of sand islands and pooled bodies of water increase, and the area of the flood plains shrink significantly. 
The distal edge of the Okavango delta experiences the lowest amount of hydrodynamic force. The distal zone also consists of more complex migration patterns such as UREM (Figure 14) and SE + CM. As a result, this region has the smallest sinuosity index and numerous crevasse splays caused by embankment crevasses. This section of the river and its secondary channels are often abandoned during the dry season and revived during the rainy season. There is only one type of distributive fluvial system. However, channel migration is controlled by many factors, and the influence of these factors on the channel is different. The erosion resistance of the source area (river valley) plays an important role in the migration of the river, which limits the lateral migration of the channel. The hydrodynamic force in the upstream area is strong, and expansion migration is dominant. After reaching the wide plain, the riverbank has low limitations with a decrease in stream power and anti-erosion ability and an increase in lateral expansion range. It is obvious that several stages of river migration overlap and the migration becomes complex. However, the decisive factors of migration also have obvious differences due to different environments. The coupled relationship between various factors needs further research.

Table 2. The average value of characterization parameters for the three zones in the Okavango delta.

\begin{tabular}{cccccc}
\hline Zone & $\mathbf{S}$ & $\mathbf{C}$ & $\boldsymbol{\Delta \theta}\left(^{\circ}\right)$ & $\mathbf{K m}$ & $\begin{array}{c}\mathbf{Q} \\
\left(\mathbf{m}^{3} / \mathbf{s e c}\right)\end{array}$ \\
\hline Axial zone & 1.91 & 0.01 & $-56-53$ & 1.69 & 313 \\
Median zone & 1.86 & 0.02 & $-57-45$ & 1.83 & 102 \\
Distal zone & 1.60 & 0.02 & $-64-54$ & 2.17 & 35 \\
\hline
\end{tabular}

$\mathrm{Q}=0.004 \mathrm{e}^{1.611 \mathrm{ln} \mathrm{w}}\left(\mathrm{Q}=\right.$ mean annual discharge; $\mathrm{L}_{\mathrm{w}}=$ meander wavelength $)[40]$.

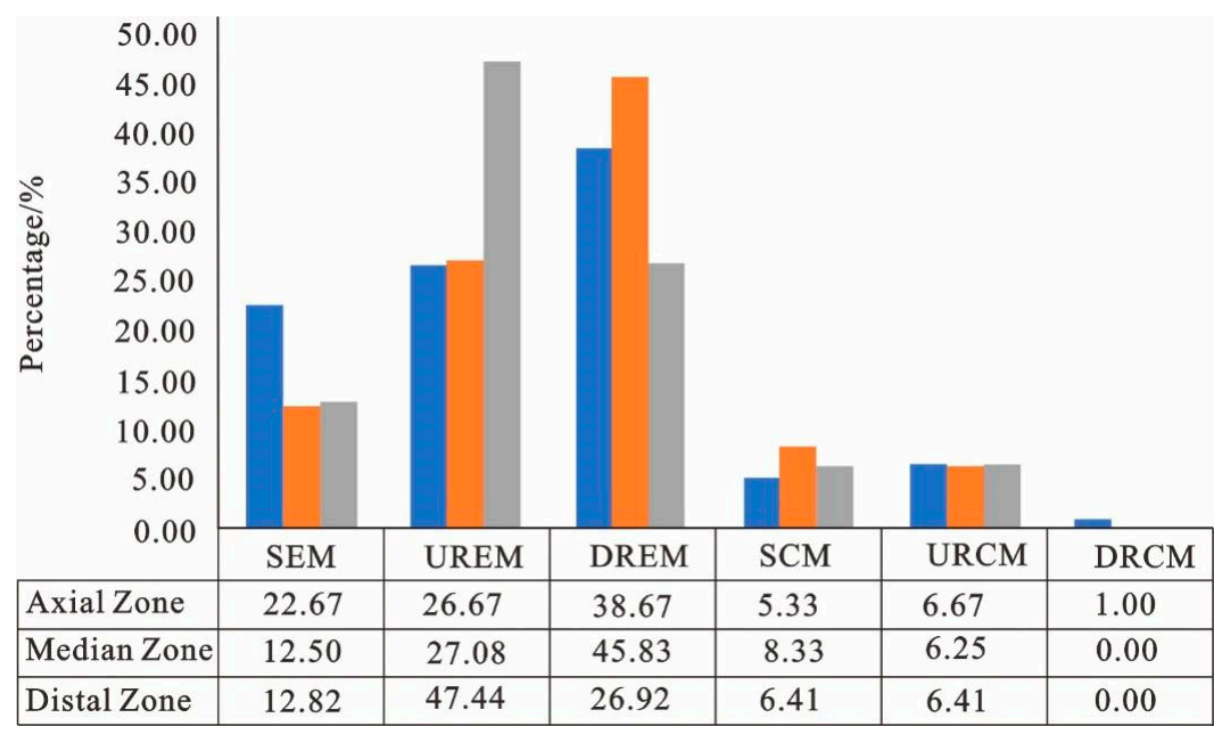

Figure 14. The percentage of different migration models in different zones based on the data of 203 meandering bends in the Okavango delta.

\subsection{Implications for Meandering River Fan Models}

The new proposed migration laws for meandering rivers result in changes to the predicted channel facies geometry and control oil and gas reservoir configurations [41-43]. Moving down the DFS, the range, morphological characteristics and properties of sedimentary facies have changed significantly. The reservoir potential in different zones is mainly controlled by the hydrodynamic and sedimentary processes. The single source meandering river fan model has extensive application value, which is more conducive to understanding a sedimentary river system. It also provides an idea for exploring more favorable reservoirs. From the apex to distal edge in DFS, the whole deposition process and deposition characteristics change systematically (Figure 13). The axial zone showed advantages of a 
confined channel belt: small slope, stronger hydrodynamic forces, lower curvature and fast migration speed. The sediment is coarse, and the channel belt is wide and deep. With continuous migration and evolution of the channel, vertical superpositions of point bars develop widely, and continuity of the reservoir sand is good. In the median zone, as the channel branches, the hydrodynamic conditions decrease and curvature increases. The point bar and channel belt are widely developed with a strong sand connection. Due to the influence of climate and vegetation, swamps and depressions are developed, which provide organic matter for oil and gas generation, and are characterized by a mud-packed sand structure. This zone has rich organic matter and is favorable for the enrichment of natural gas, which is conducive to the accumulation of oil and gas and developing high-quality reservoirs. In the distal zone, the river entered an arid to semi-arid environment with weak hydrodynamic conditions. Under the influence of seasonal climate and landforms, the river is characterized by the development of a straight river with high curvature. The connectivity of sand becomes poor, and the effective reservoir decreases. More distal channels on the DFS show curved or similar distribution models (Figure 13). This further shows that the aggregate shape and heterogeneity of river reservoirs are more complex.

\section{Conclusions}

Based on sedimentary and geomorphological observations from satellite images, the various features in a meandering river fan are characterized. The conclusions are as follows.

By examining meandering channel elements, six single modes and three compound modes of channel morphology were identified. The six single-channel morphology modes are symmetrical expansion migration (SEM), upstream rotation expansion migration (UREM), downstream rotation expansion migration, contraction migration (SCM), upstream rotation contraction migration (URCM) and downstream rotation contraction migration (DRCM). The three compound modes of channel morphology are symmetrical expansion and contraction migration $(\mathrm{SE}+\mathrm{CM})$, upstream rotation expansion and contraction migration $(\mathrm{URE}+\mathrm{CM})$ and downstream rotation expansion and contraction migration $(\mathrm{DRE}+\mathrm{CM})$.

In this research, lateral upstream migration of the channel is limited, while the lateral migration range of the downstream becomes larger. River branches and diversions can also be seen, with continual migration and superposition of point bars. Five meandering loops and four abandoned and active channels have been identified. While observations of the present-day sedimentary facies cannot be directly applied to the paleoenvironment, our observations of the river migration modes have important implications for river reconstruction and restoration.

With respect to DFS, the study area can be divided into three zones. The axial zone is characterized by the expansion migration with UREM + CM and SE + CM; the median zone contains expansion migration, $\mathrm{SE}+\mathrm{CM}$ and $\mathrm{URE}+\mathrm{CM}$; the distal zone developed expansion migration, $\mathrm{SE}+\mathrm{CM}$, and tended to be straight with little to no evidence of migration over time.

Author Contributions: Conceptualization, J.Z. and X.Y.; methodology, J.Z. and X.Y.; software, X.Y.; formal analysis, X.Y.; investigation, Y.L. and L.S.; data curation, X.Y.; writing —original draft preparation, X.Y. and Y.L.; writing-review and editing, X.Y. and Y.L. All authors have read and agreed to the published version of the manuscript.

Funding: This research was funded by [Project funded by China Postdoctoral Science Foundation] grant number [2021M700537].

Institutional Review Board Statement: Not applicable.

Informed Consent Statement: Not applicable.

Data Availability Statement: The data presented in this study are available upon request from the corresponding author.

Conflicts of Interest: The authors declare no conflict of interest. 


\section{References}

1. Deb, M.; Das, D.; Uddin, M. Evaluation of meandering characteristics using RS \& GIS of Manu River. J. Water Resour. Prot. 2012, 4, 163-171.

2. Boothroyd, R.J.; Williams, R.D.; Hoey, T.B.; Barrett, B.; Prasojo, O.A. Applications of Google Earth Engine in fluvial geomorphology for detecting river channel change. Wiley Interdiscip. Rev. Water 2020, 8, e21496. [CrossRef]

3. Weissmann, G.S.; Hartley, A.J.; Scuderi, L.A.; Nichols, G.J.; Owen, A.; Wright, S.; Felicia, A.L.; Holland, F.; Anaya, F.M.L. Fluvial geomorphic elements in modern sedimentary basins and their potential preservation in the rock record: A review. Geomorphology 2015, 250, 187-219. [CrossRef]

4. Rowland, J.C.; Shelef, E.; Pope, P.A.; Muss, J.; Gangodagamage, C.; Brumby, S.P.; Wilson, C.J. A morphology independent methodology for quantifying plan view river change and characteristics from remotely sensed imagery. Remote Sens. Environ. 2016, 184, 212-228. [CrossRef]

5. Leopold, L.B.; Bagnold, R.A.; Wolman, M.G.; Brush, L.M. Flow Resistance in Sinuous or Irregular Channels: Professional Paper 282-D; Government Printing Office: Washington, DC, USA, 1960.

6. $\quad$ Leopold, L.B.; Maddock, T., Jr. The Hydraulic Geometry of Stream Channels and Some Physiographic Implications: Professional Paper 252; Government Printing Office: Washington, DC, USA, 1953.

7. Leopold, L.B.; Wolman, M.G. River Channel Patterns: Braided, Meandering, and Straight: Professional Paper 282-B; Government Printing Office: Washington, DC, USA, 1957.

8. Wolman, M.G.; Miller, J.P. Magnitude and frequency of forces in geomorphic processes. J. Geol. 1960, 68, 54-74. [CrossRef]

9. Brice, J.C. Evolution of meander loops. GSA Bull. 1974, 85, 581-586. [CrossRef]

10. Hooke, J.M. Changes in river meanders: A review of techniques and results of analyses. Prog. Phys. Geogr. 1984, 8, 47-508. [CrossRef]

11. Hooker, J.M. Processes of channel planform change on meandering channels in the UK. In Changing River Channels; Gurnell, A., Petts, G.E., Eds.; John Wiley and Sons: Chichester, UK, 1995; pp. 87-115.

12. Weissmann, G.S.; Hartley, A.J.; Nichols, G.J.; Scuderi, L.A.; Olson, M.; Buehler, H.; Banteah, R. Fluvial form in modern continental sedimentary basins: Distributive fluvial systems. Geology 2010, 38, 39-42. [CrossRef]

13. Hartley, A.J.; Weissmann, G.S.; Nichols, G.J.; Warwick, G.L. Large distributive fluvial fystems: Characteristics, distribution, and controls on development. J. Sediment. Res. 2016, 80, 167-183. [CrossRef]

14. Davidson, S.K.; Hartley, A.J.; Weissmann, G.S.; Nichols, G.J.; Scuderi, L.A. Geomorphic elements on modern distributive fluvial systems. Geomorphology 2013, 180, 82-95. [CrossRef]

15. Blum, M.; Martin, J.; Milliken, K.; Garvin, M. Paleovalley systems: Insights from quaternary analogs and experiments. Earth-Sci. Rev. 2013, 116, 128-169. [CrossRef]

16. Shan, J.; Ji, Z.; Zhao, Z.; Li, F.; Sun, L.; Zhang, B.; Fang, S. Analysis of sedimentary and evolution process for underground meandering river point bar: A case study from No. 23 thin layer of Yangdachengzi oil reservoir in Jilin oilfield. Acta Pet. Sin. 2015, 36, 809-819.

17. Schuurman, F.; Kleinhans, M.G.; Middelkoop, H. Network response to disturbances in large sand-bed braided rivers. Earth Surf. Dyn. 2016, 4, 25-45. [CrossRef]

18. Elina, K.; Leena, L.; Eliisa, L.; Petteri, A. Flow patterns and morpho-logical changes in a sandy meander bend during a flood: Spatially and temporally intensive ADCP measurement approach. Water 2017, 9, 106.

19. Lin, Z.P.; Shan, J.F.; Chen, L. Geomorphology processes of channel planform migration on meandering rivers. Acta Geol. Sin. 2017, 91, 134-135. [CrossRef]

20. Lin, Z. Migration structures of meandering channels. Int. J. Inf. Res. Rev. 2017, 6, 4213-4221.

21. Li, Y.; Zhang, J.L.; Xu, Y.H.; Chen, T.; Liu, J.S. Improved understanding of the origin and accumulation of hydrocarbons from multiple source rocks in the Lishui Sag: Insights from statistical methods, gold tube pyrolysis and basin modeling. Mar. Pet. Geol. 2021, 134, 105361. [CrossRef]

22. McCarthy, T.S.; Barry, M.; Bloem, A.; Ellery, W.N.; Heister, H.; Merry, C.L.; Röther, H.; Sternberg, H. The gradient of the Okavango fan, Botswana, and its sedimentological and tectonic implications. J. Afr. Earth Sci. 1997, 24, 65-78. [CrossRef]

23. Wilson, B.H.; Dincer, T. An introduction to the hydrology and hydrography of the Okavango Delta. In Proceedings of the Symposium on the Okavango Delta and Its Future Utilization; Botswana Society: Gaborone, Botswana, 1976; pp. $33-48$.

24. Tooth, S.; McCarthy, T.S. Controls on the transition from meandering to straight channels in the wetlands of the Okavango Delta, Botswana. Earth Surf. Process. Landf. 2004, 29, 1627-1649. [CrossRef]

25. Stanistreet, I.G.; McCarthy, T.S. The Okavango Fan and the classification of subaerial fan systems. Sediment. Geol. 1993, 85, 115-133. [CrossRef]

26. Stanistreet, I.G.; Cairncross, B.; McCarthy, T.S. Low sinuosity and meandering bedload rivers of the Okavango Fan-Channel confinement by vegetated levees without fine sediment. Sediment. Geol. 1993, 85, 135-156. [CrossRef]

27. McCarthy, T.S.; Ellery, W.N. The Okavango Delta. Trans. R. Soc. S. Afr. 1998, 53, 157-182. [CrossRef]

28. Gumbricht, T.; McCarthy, J.; McCarthy, T.S. Channels, wetlands and islands in the Okavango Delta, Botswana, and their relation to hydrological and sedimentological processes. Earth Surf. Process. Landf. 2010, 29, 15-29. [CrossRef]

29. Murray-Hudson, M.; Combs, F.; Wolski, P.; Brown, M.T. A vegetation-based hierarchical classification for seasonally pulsed floodplains in the Okavango Delta, Botswana. Afr. J. Aquat. Sci. 2011, 36, 223-234. [CrossRef] 
30. McCarthy, T.S.; Stanistreet, I.G.; Cairncross, B. The sedimentary dynamics of active fluvial channels on the Okavango fan, Botswana. Sedimentology 1991, 38, 471-487. [CrossRef]

31. Fryirs, K.A.; Ralph, T.J.; Larkin, Z.T.; Tooth, S.; Humphries, M.; McCarthy, T.; Hesse, P.P.; Mosimanyana, E. A nested hierarchical perspective to enhance interpretations and communication in fluvial geomorphology for use in water resources management: Lessons from the Okavango Delta, Botswana. Geogr. J. 2018, 184, 192-207. [CrossRef]

32. McCarthy, T.S.; Ellery, W.N.; Stanistreet, I.G. Avulsion mechanisms on the Okavango fan, Botswana: The control of a fluvial system by vegetation. Sedimentology 1992, 39, 779-795. [CrossRef]

33. Jackson, R.G. Depositional model of point bars in the lower Wabash River. J. Sed. Petrol. 1976, 46, 579-594.

34. Smith, D.G.; Hubbard, S.M.; Lavigne, J.R.; Leckie, D.A.; Fustic, M. Stratigraphy of counter-point-bar and eddy-accretion deposits in low-energy meander belts of the Peace-Athabasca Delta, northeast Alberta, Canada. In From River to Rock Record: The Preservation of Fluvial Sediments and Their Subsequent Interpretation; Davidson, S., Leleu, S., North, C.P., Eds.; SEPM Special Publication: Broken Arrow, OK, USA, 2011; Volume 97, pp. 143-152.

35. Ielpi, A.; Ghinassi, M. Planform architecture, stratigraphic signature and morphodynamics of an exhumed Jurassic meander plain (Scale-by Formation, Yorkshire, UK). Sedimentology 2014, 61, 1923-1960. [CrossRef]

36. Lin, Z.P.; Shan, J.F.; Chen, L.; Sun, Q.J.; Wang, Y.W.; Wang, F. Geomorphology processes of channel planform migration on modern meandering rivers. J. Sedimentol. 2018, 36, 427-445.

37. Wolski, P.; Murray-Hudson, M. Flooding dynamics in a large low-gradient alluvial fan, the Okavango Delta, Botswana, from analysis and interpretation of a 30-year hydrometric record. Hydrol. Earth Syst. Sci. Discuss. Eur. Geosci. Union 2005, 2, 1865-1892. [CrossRef]

38. Frascati, A.; Lanzoni, S. Morphodynamic regime and long-term evolution of meandering rivers. J. Geophys. Res. 2009, 114, F02002. [CrossRef]

39. Shan, J. Architectural Element Method for Fluvial Reservoir; Science Press: Beijing, China, 2017.

40. Carlston, C.W. The relation of free meander geometry to stream discharge and its geomorphic implications. Am. J. Sci. 1965, 263, 864-885. [CrossRef]

41. Hooke, J. Coarse sediment connectivity in river channel systems: A conceptual framework and methodology. Geomorphology 2003, 56, 79-94. [CrossRef]

42. Gilvear, D.; Winterbottom, S.; Sichingabula, H. Character of channel planform change and meander development: Luangwa River, Zambia. Earth Surf. Process. Landf. 2000, 25, 421-436. [CrossRef]

43. Wu, C.L.; Bhattacharya, J.P.; Ullah, M.S. Paleohydrology and 3D facies architecture of ancient point bars, Ferron Sandstone, Notom Delta, South-Central Utah, USA. J. Sediment. Res. 2015, 85, 399-418. [CrossRef] 